RESEARCH ARTICLES

\title{
Analysis the Impact of Literature on the Formation of the Russian Federation State Civil Servant Image in Mass Media
}

\section{Análisis del impacto de la literatura en la formación de la imagen del funcionario público de la Federación de Rusia en los medios de comunicación}

\section{Tatiana A. Evstratova*}

Russian State Social University, Moscow, Russia

ORCID: https://orcid.org/0000-0002-4099-0761

Natalia V. Medvedeva

Russian State Social University, Moscow, Russia

ORCID: https://orcid.org/0000-0001-5998-6781

\section{Liudmila A. Kalinichenko}

Research Institute of Prospective Directions and Technologies, Russian State Social University, Moscow, Russia

ORCID: https://orcid.org/0000-0002-8973-8081

*Correspondence

Email: doroshenkot@yandex.ru
Cite as:

Evstratova, T. A., Medvedeva, N. V., \& Kalinichenko, L. A (2020). Analysis the Impact of Litreature on the Formation of the Russian Federation State Civil Servant Image in Mass Media n. Propósitos y Representaciones, 8(2), e506. doi: http://dx.doi.org/10.20511/pyr2020.v8n2.506 


\section{Summary}

The main features of the XXI century Russian society have been formed due to social and psychological changes, which led to a global transformation of the state system. Modern world faces the problem of developing a new policy of state power that will be based on the principles of consensus (reconciliation of all contentious and conflicting issues in the process of developing a solution that is reached through discussion and consultation), society and open partnership. The reason for this global upheaval is that the pace of change in the relationship between the state (government) and society itself depends on the open-ended policy that is now key. The image of a civil servant is similar to a construction that can be replaced, strengthened, re-mounted, modified, etc., and most importantly, that it needs serious work. The perception of the image exists and changes not only in the consciousness of people, but also in the unconscious sphere (emotional). In order to create a positive image of a civil servant, they need to be governed. To manage it, one needs to know the basic idea of what and in what sequence should occur, and at what stage intermediate results should appear. According to the authors, the solution to the problem of studying the acting factors that make the positive image of civil servants of modern Russia, the identification of the most effective ways, forms and principles of its positive transformation, as well as the analysis of the constituents of the employee of state structures are relevant. The most important in the work of representatives of public authorities is the nature of their public relations. If public servants do not evoke citizens' feelings of trust, justice and other positive psychological and social reactions, then feedback (from the population to state bodies) will be ineffective. Since the operation of the system of state power is the result of the functioning of the whole state as a whole, it is important that the work of state bodies used the maximum opportunities with the least cost. This scheme ensures effective management and positive results. But such a situation will not be achievable if the level of public trust in government is low.

Keywords: State Civil Servant, Public Servant Image, Media.

\section{Resumen}

Las principales características de la sociedad rusa del siglo XXI se han formado debido a cambios sociales y psicológicos, que condujeron a una transformación global del sistema estatal. El mundo moderno enfrenta el problema de desarrollar una nueva política de poder estatal que se basará en los principios de consenso (conciliación de todos los temas conflictivos y conflictivos en el proceso de desarrollar una solución que se alcance a través de la discusión y consulta), la sociedad y la asociación abierta. La razón de esta agitación global es que el ritmo de cambio en la relación entre el estado (gobierno) y la sociedad misma depende de la política abierta que ahora es clave. La imagen de un funcionario público es similar a una construcción que se puede reemplazar, fortalecer, volver a montar, modificar, etc., y lo más importante, que necesita un trabajo serio. La percepción de la imagen existe y cambia no solo en la conciencia de las personas, sino también en la esfera inconsciente (emocional). Para crear una imagen positiva de un funcionario público, deben ser gobernados. Para gestionarlo, es necesario conocer la idea básica de qué y en qué secuencia debe ocurrir, y en qué etapa deben aparecer los resultados intermedios. Según los autores, la solución al problema de estudiar los factores de actuación que hacen la imagen positiva de los funcionarios de la Rusia moderna, la identificación de las formas, formas y principios más efectivos de su transformación positiva, así como el análisis de los componentes del empleado de las estructuras estatales son relevantes. Lo más importante en el trabajo de los representantes de las autoridades públicas es la naturaleza de sus relaciones públicas. Si los servidores públicos no evocan los sentimientos de confianza, justicia y otras reacciones psicológicas y sociales positivas de los ciudadanos, la retroalimentación (de la población a los organismos estatales) será ineficaz. Dado que la operación del sistema de poder estatal es el resultado del funcionamiento de todo el estado en su conjunto, es importante que el trabajo de los organismos estatales aproveche las máximas oportunidades con el menor costo. Este esquema garantiza una gestión eficaz y 
resultados positivos. Pero tal situación no será posible si el nivel de confianza pública en el gobierno es bajo.

Palabras clave: Funcionario estatal; Imagen de funcionario público; Medios.

\section{Introduction}

The most crucial factor in the commitment to democratic values and the exercise of the will of the Russian people is the institute of public opinion, as it is the link between the population and the government, the state and civil society.

The creative potential of the people, their assessment of the activity of power structures is expressed in the form of public opinion, which is the most important means of forming a positive image of civil servants in modern Russia. Public trust and understanding can only be achieved if civil servants themselves seek to provide citizens with as objective, reliable and complete information as possible about their actions and decisions, that is, to follow the principles of information transparency (such a state of awareness of any activities, objects, results, which allows any interested entity to have their complete understanding).

The problem is determined by the contradiction between the professional labor-intensive work of responsible civil servants on the one hand, and the often-negative attitude of the population to the civil service institution on the other.

The relevance of the problem of forming a positive image of the civil servant has aggravated also due to the fact that the media have performed both the information and evaluation function recently. In this case, the media can bring not only a positive element in the formation of the image but also a negative one. It is regrettable that the image of the system of state power in the eyes of the Russians is now largely depends on reports received by citizens from the media, who use information from their unverified sources or try to seek sensations determined by the political situation.

In February 2019, a well-known Russian scientific journal - SotsIs (Sotsis Magazine, 2019) conducted a scientific study, which showed features of the image of a civil servant of the Russian Federation formed in the minds of citizens of the Russian Federation. This study (survey) was conducted in the city of Moscow, the number of respondents was 700 people of different age categories (from 18 to 70 years).

The questionnaire considered how the population evaluated the work of public authorities. The survey results were disappointing:

a) effective - $6 \%$;

b) insufficiently effective - $63 \%$;

c) ineffective $-31 \%$.

Also interesting were the results of a survey whose authors sought to find out from citizens what a modern civil servant is. $16 \%$ of the respondents said they imagine a modern civil servant as decent, honest and polite, but the majority (79\%) imagine a negative image of a civil servant. Moreover, the respondents explained that the most common negative quality of the civil servant is mercantilism - 54\%, the other 5\% did not answer this question.

Negative image creates and develops a number of global and urgent problems within the interconnection between public authorities and the population. Therefore, the formation of a positive image of a Russian civil servant is an urgent task of development of the country under the present conditions (Sokolova, 2010). 
People's dissatisfaction with the quality of work of the Russian government and the moral and business image of its representatives, which formed a negative image of a civil servant, has firmly rooted in the mass consciousness and has become the commonplace of many publications devoted to the problems of public service (Official Statistics of Russia, 2018).

Indeed, as numerous studies show, the image of the modern Russian civil servant for a considerable part of citizens is quite repulsive: a bureaucrat, a corrupt person, who use their powers predominantly selfishly (Ageev, 2000). In this case, a person who does not bear the slightest responsibility for his/her actions, is prone to arbitrariness, taking up from the compatriots a lot of time and in every way preventing any meaningful and creative activity (Atamanchuk, 1997).

As one of the most significant factors in the formation of a negative image of a civil servant, not unreasonably, are media. It seems that television and radio broadcasts, publications with loud revelations of government officials appear almost every day (Voitasik, 2007). However, in order to increase the efficiency of bodies and divisions of the public administration, whose sphere of competence is public relations, it is important to know what the content of the image of a public servant developing under the influence of the media really is.

\section{Problem Statement}

Currently, many authors are interested in forming a positive image of a civil servant. The image of public servants has become the subject of studies by S.M. Seregin, L.I. Burganova. (Seregin, 2015; Burganova, 2014). The sociological researches devoted to the estimation of population of work of state bodies and civil servants by the professor of the Russian Academy of Public Service under the President of the Russian Federation - K.O. Magomedov are of interest (Magomedov, 2010).

Western authors have developed various technologies for forming a positive image of public servants, such as social networks and media technologies media (Mehraj, Bhat \& Mehraj, 2014) and television (Liebes, 1992)

The results of this study, both theoretical and practical, can contribute to the formation of a positive image of public servants, to promote staff renewal of public service, the revision of professional norms of ethics and a positive perception of the population of public authorities.

\section{Research Issue}

How does the image of the Russian civil servant in the media form? What image of the civil servants (positive or negative) do the media form? How does this affect the public opinion?

\section{Objective}

To form a positive image of a civil servant of the Russian Federation, it is necessary to solve some problems. These include the creation of a system of interconnection of public administration and the public, updating of the construction of information policy, improvement of the corporate image of the civil service, modification of the culture of the organization, and application of the basics of marketing. Modern management approaches require open access to information of an organizationally planned and socially everyday nature (Vetrova, Medvedeva, Kabanova, Evstratova \& Senicheva, 2019).

To implement a program to develop a positive image of a civil servant of the Russian Federation, it is necessary to do some things: 
(a) develop and approve the proper policy strategy for a specific body. In this case, the main task will be to determine the goals, tasks, powers, functions, and schemes of relationships of officials in the team;

b) organize the creation of a special department for public relations, break it into divisions and include them in the general system of approval of decisions in the sphere of government;

c) upgrade the personnel system, to provide compulsory training only for recruited employees and retraining of already employed employees, tighten the certification and recruitment requirements for employees, etc.

After all these conditions are fulfilled, the next step to get a positive PR will be to change the system and improve communication with the media.

Modern Russian media pursue their own interests in covering the activities of state authorities and their representatives. They make their own decisions about what to write and what to show. Therefore, only independent improvement of the civil service, in general, will highlight the media and the positive image of the civil servant.

According to official statistics (www.gosstat.ru), in the fifth part of the publications, the founders include some authority. This figure reaches $81 \%$. Accordingly, state authorities, which are the founders of various media, have the power to determine their information policy in the desired way (Official Statistics of Russia).

As for independent media, they can use and manage information at their discretion. This strategy provides for:

- creation of own independent information flow (monopoly on specific information);

- management of novelties (interpretation, distribution of accents, competent choice of quotes, use of emotional material);

- information interaction (provision of exclusive events and news by accredited media);

- updating and better shape and style of media materials.

Effective instruction of the population requires civil servants to meet with residents periodically. With this form of interaction, verbal contact is made, and residents will be able to directly ask the question that interests them. Receiving a response in person from a civil servant will raise his authority in their eyes.

Another form of interaction is a hotline with the public. In a few hours a civil servant will be able to answer people's questions, find out about their problems, state of affairs, help on the spot with a council or take control to answer the task in a responsible way.

To enhance the positive image of the civil servant in situ, that is, in the departments, state bodies, institutions, it is necessary to create ethical commissions. They can include both employees and representatives of trade union organizations, administration and other people with a spotless reputation.

The members of the ethics committee will be obliged to form, develop and implement moral norms of behavior of civil servants in situ, to resolve conflicts of various kinds, including moral ones.

In the case of any violation of generally accepted norms and rules of conduct, commitment of any immoral acts, members of the ethics committee will have the right to make a public reprimand on their own or to apply to the relevant structures with a request for administrative punishment with all the consequences that follow, including dismissal of the offender. 
If all the above norms are observed and implemented, the formation of a positive image of a civil servant will come faster and more qualitatively, and may become part of the general image of the civil service against the background of information policy.

\section{Methods}

To reveal the peculiarities of forming the image of the civil servants of the Russian Federation in the media, the authors conducted a content analysis on "The image of a civil servant in modern Russia".

The object of research of content analysis are newspapers, electronic publications, which sections discuss the image of public servants of the Russian Federation (heads and specialists of departments, deputy ministers, heads of administrations, etc.) and/or bodies and divisions of the state apparatus. Mentions of the President, governors, the chairman and members of the Government of the Russian Federation, deputies of legislative bodies were not included in the review (Dmitriev, 2005).

This approach is mostly consistent with the definitions of "civil service" and "civil servant" adopted in the legislation and allows clearly identifying the criteria of belonging of the subjects of analysis to the category "civil servant" (Federal Law of the Russian Federation "On Civil Service of the Russian Federation" No. 79 Federal Law of the Russian Federation of July 27, 2004; Federal Law of the Russian Federation "On the System of the Civil Service of the Russian Federation" No. 58-Federal Law of the Russian Federation of May 27, 2003; Federal Law of the Russian Federation No. 2124 -1 "On Mass Media" of December 27, 1991).

The subject of the study is the content of media columns devoted to the image of civil servants published from February 1, 2018, to April 1, 2019.

The purpose of the study is to present a generalized image of a Russian civil servant formed by the media.

The task of the study is as follows:

1) Analyze the content of columns devoted to the topic of image of civil servants of the Russian Federation by means of a codifier. the media.

2) Reveal how the image of the civil servant of the Russian Federation is formed through Federation.

3) Identify the main topics that affect the image of civil servants of the Russian

\section{Results}

Selection of numbers for analysis was made on the basis of the principles of sample research of documentary sources. Sampling was $10 \%$ of the total number of newspaper issues - from the first week of February 2018 to the first week of April 2019. For analysis, every tenth number was published for the period. The total number of selected numbers for the study was 237 units. The total number of publications eligible for analysis was 204. Units of meaning were text fragments (from one sentence) containing the following factors:

public image: 1) list, 2) quality, 3) terms of performance, 4) cost of services, 5) location of authorities, 6) professionalism of its employees; image for entrepreneurs: 7) level of loyalty thereto, 8) reliability, 9) representation of entrepreneurs about its goals and objectives stated in the Charter, 10) information openness of state bodies; image for state structures: 11) importance of state bodies of power, 12) their participation in solving state problems, 13) compliance with the legislation of the Russian Federation, 14) openness to informal contacts; 
social image: 15) social actions conducted by state bodies, 16) information openness, 17) compliance with environmental standards, 18) the number of jobs provided, 19) public presentation of its goals and objectives stated in the Charter.

To identify the state of the image, the author evaluated the degree of conformity of each parameter of all 19 of its components to a positive one and made the following estimates:

"5" - if the status of this parameter completely matches the image;

"4" - if the status of this parameter does not completely match the image;

"3" - if the status of this parameter slightly matches the image;

"2" - if the status of this parameter does not completely match the image.

For content analysis, the author selected the following newspapers and electronic publications: "Lenta.ru" (Electronic news of "Lenta.ru, 2019), "Novosti_mail.ru" (Electronic news of "Novosti_mail.ru") "Russkaia Planeta" (Electronic news of "Russkaia Planeta", 2019), "RIA Novosti" (Electronic news of "RIA Novosti", 2019).

A total of 1096 articles were analyzed (total volume of the analyzed publications), 521 (the volume of content of the text directly related to the problem under study) presented above. This analysis can be presented in Table 1 .

Table 1.

Image parameters and Parameter compliance evaluation

\begin{tabular}{lcc}
\hline Image parameters & Parameter compliance evaluation \\
\cline { 2 - 3 } & Negative image & Positive image \\
\hline List of services & 3 & 5 \\
Quality of services & 4 & 5 \\
Terms of services & 3 & 4 \\
Cost of services & 3 & 5 \\
Location of the authorities & 4 & 5 \\
Professionalism of its employees & 4 & 5 \\
Loyalty level to entrepreneurs & 2 & 5 \\
Reliability & 3 & 5 \\
Entrepreneurs' view of stated goals and objectives & 2 & 5 \\
Information openness of state bodies & 5 & 5 \\
importance of state authorities & 5 & 5 \\
participation in solving state problems & 5 & 5 \\
compliance with the laws of the Russian Federation & 5 & 5 \\
openness to informal contacts & 3 & 4 \\
social actions conducted by state bodies & 4 & 5 \\
information openness & 3 & 5 \\
compliance with environmental standards & 5 & 5 \\
the number of jobs available & 5 & 4 \\
public presentation of its goals and objectives & 2 & 5 \\
Mean & 3.68 & 4.84 \\
\hline
\end{tabular}

According to the results of this analysis, the hypothesis that "the media creates a negative image of civil servants, which affects the opinion of the population" was refuted. 
From February 2018 to April 2019, electronic and newspaper editions published news, all reviewed newspapers wrote negative and positive columns about Russian civil servants; some editions ("RIA Novosti", "Lenta.ru", "Moskovsky Komsomolets") wrote more negative articles, some ("Metro") - almost only positive.

Based on this content analysis on "Image of a civil servant of the Russian Federation", we can conclude that for a year and 2 months, electronic and print publications publish $10 \%$ more positive information than negative (55.09\% - positive articles; $44.91 \%$ - negative articles), which indicates that the negative opinion is formed by the media - false.

Interesting fact is that the information that reflects the image of a civil servant of the Russian Federation somehow depends on the affiliation of the publication to independent journalistic materials or the support of state positions (Komarovskii, 2003).

Having analyzed the data obtained during the research, it is possible to draw up a social and psychological portrait of a modern civil servant (based on the articles reviewed).

Thus, a civil servant is hardworking, but at the same time he seeks his own gain (scam); this problem is based not only on personal characteristics, but also on the motivation system of civil servants of the Russian Federation (Kokhanov, 2009).

The situation when the population faces daily complication of certain problems, long queues at receptions, rudeness and incompetence of individual authorities, corruption phenomena, etc., continues to deepen and contribute to the formation of a negative Russian citizen image employee (Code of Ethics of the Civil Servant of the Russian Federation, 2010).

The "revelatory" or critical media materials that satisfy the reader's and television audience's requests for scandalous facts also play a huge role. The study confirmed this fact. Publications on topics devoted to Russian civil servants and authorities in the electronic publication Lenta.ru and Moskovsky Komsomolets were published mainly in "Crime" and "Politics" sections.

Referring to the results of the study, the author concludes that the media is not a valid reason for the formation of a negative image of a Russian civil servant. According to the author, the negative image of the state civil servant of the Russian Federation in the consciousness of the population forms a personal experience, as well as "word of mouth" (rumors). Content analysis also included articles that contained testimonies from citizens, witnesses, and participants in the involvement of civil servants of various institutions in their corruption and bribery.

The modern organizational culture of employees at the state level has its own characteristics, whose presence and implementation contributes to the ability to distinguish their own culture of the organization from others. Also, for state employees, such features are a source of high-level personal and personal activity, in accordance with current legal norms and traditions.

Organizational culture of civil servants implies a combination of values, trends, traditions, concepts of beliefs and norms of behavior, which determine how a civil servant shall act in a number of situations.

The culture of the organization transforms the structure of motivation, develops and establishes the principle of behavior, implements itself in the style of management, the constitution of the organization, its managerial and organizational activities. It also influences the culture of employee behavior and the functioning of the organization in general; attitude of employees to each other, to the institution, and to the results of the organization. 

institutions.

Hence, we can conclude that organizational culture plays a large role in government

The development of an in-house code of conduct is a set of various activities that, through the influence and constituents of external and internal factors of the organization (with the help of external collections of values, manners of leadership, norms and principles of behavior, appearance, traditions, rules, rewards and punishments), taking into account the complex current state, aims to increase the effectiveness of the organization, in accordance with the aspirations and tasks set out in the regulatory and legal acts of the Russian Federation, present in public requests and provided by management.

\section{Discussion}

The impact of the formation of the culture of the organization affects the performance of civil servants, which main criteria are:

- high spirits of employees;

- its daily strengthening;

- observance of standards of code of conduct by employees;

- adherence to the norms of business ethics;

- education and support of a positive image;

- education and development of organizational style.

The corporate spirit of employees is formed with a great sense of responsibility for the results of their work.

The main methods for strengthening the corporate atmosphere of employees are:

- bringing tasks and strategic ideas of state bodies to all employees;

- promotion of tasks and strategic goals, bringing them to all levels;

- informing all employees of their place in the structure, their role in achieving strategic goals;

- observing celebrations in the organization;

- promoting organizational style;

- promoting sports lifestyle among employees and promotion of sports clubs;

- involving young people in the civil service, their development and capacity building;

- forming personnel potential of the organization.

Another important principle is the observance of ethics rules in organizational behavior.

These principles of etiquette include friendliness and sincerity of employees, truthfulness and honesty, respect and tact, rights and individual respect between employees.

Also, one of the main roles in the culture of the civil servant organization is to follow the rules of business ethics, which form organizational behavior.

Each civil servant must exercise his or her professional duties in good faith and with discretion, preventing a possible conflict of interest. It is necessary to create an environment for ensuring compliance with one's own activity, in accordance with the current legislative norms, ethical criteria and public rules of business turnover.

The main rules and principles of business ethics of civil servants:

- adherence to legislation and internal regulatory documentation;

- protection of internal information sources; 
- confidentiality;

- solving conflict situations by negotiation and agreement;

- discipline;

- desire to raise the professional level;

- focus on the result;

- wise activity, vigorousness, initiative;

- the ability to make smart decisions, including risky and innovative ones;

- support of ideas and desire to increase efficiency of work;

- the ability to treat their responsibilities not only as a source of income and career growth, but also as a way of meeting their needs and self-expression;

- adherence to business style in clothing;

- the ability to prevent conflicts of interest.

The principle of forming and maintaining a positive image also plays a significant role in the organizational culture.

Positive image of the organization is a long-term task. The main factors of a positive image of the organization are:

- $\quad$ skillful cooperation with media sources;

- transparency and accessibility of elements of the organizational culture;

- support to the values of the organizational culture;

- social policy and provision of motivation for employees.

Norms of formation and support of positive image relate closely to the principle of formation and improvement of organizational style.

Organizational style is an important factor that influences the prestige of the organization and the strategy of its social cooperation. It is established in accordance with the set goals, strategic goals, orientations in accordance with the main principles of the organization's culture.

The style of the organization is externally expressed in symbolism - color, logo, flag and other details, which are visually reflected in the design of offices, buildings and their staff, as well as in special accessories.

Another element of the organizational style is the principles of communication - its own page on the Internet, e-mail address, social networks, periodicals, etc.

During the formation of the culture of the organization, it is necessary to remember that it is not only a way of improving its functional efficiency as an operating mechanism and object of society, but an integral part of the organizational ideology of development and modernization, where the leadership, as well as members of the team, must play their own role. Only a common desire to raise the culture of the organization can transform both the employees and the structure into a single team working solely for a positive result. Positive image can make such a profession as a civil servant attractive for young people, helping to solve problems in employment, forming living standards and social guidelines for youth (Evstratova, Vetrova,\& Kabanova, 2019).

\section{References}

Ageev, V. S. (2000). Mechanisms of social perception. St. Petersburg: Piter, pp. 109-131.

Atamanchuk, G. V. (1997). The State Service of the Russian Federation: first steps and prospects. Moscow, pp. 56-61.

Burganova, L. I. (2014). Public service imaging by media. L. Burganova, S. Bataikina. Power, 3, $42-45$. 
Code of Ethics for Civil Servants of the Russian Federation, (2010). http://www.rb.ru/inform/98977.html (accessed date 10.01.2020).

Dmitriev, I. (2005). Content analysis: nature, tasks, procedures. St. Petersburg: Piter, pp. 42-71. Electronic edition of "Lentra.ru". http://lenta.ru (accessed date: 10.10.2019).

Electronic edition of "RIA Novosti" http://m.ria.ru (accessed date 28.09.2019).

Electronic edition of "Novosti_mail.ru". http://news.mail.ru (accessed date 12.12.2019).

Electronic edition of "Russkaya Planeta" http://rusplt.ru (accessed date 21.09.2019).

Evstratova, T. A., Vetrova, E. A., \& Kabanova, E. E. (2019). Youth Employment In Megalopolis: Regulation, Modern Tendencies And Development Model. In The European Proceedings of Social \& Behavioural Sciences EpSBS (pp. 233-243).

Federal Law of the Russian Federation (1991). No. 2124-1 "On Mass Media” of December 27.

Federal Law of the Russian Federation (2003). No. 58-FZ "On the Civil Service System of the Russian Federation" of May 27.

Federal Law of the Russian Federation (2004). No. 79-FZ "On State Civil Service of the Russian Federation" of July 27.

Kokhanov, E. F. (2009). Genesis of structures and models of public relations. Management in Russia and abroad, 6, 35-38.

Komarovskii, V. S. (2003). Public Service and Mass Media. Voronezh: E.A. Bolhovitinov Publishing house, pp. 12-23.

Liebes, T. (1992). Decoding television news: The political discourse of Israeli hawks and doves. Theory and society, 357-381.

Magomedov, K. O. (2010). The image of public service as an image of public authority. Public service. Bulletin of the Coordinating Council on Personnel, State Awards and Civil Service under the Plenipotentiary Representative of the President of the Russian Federation in the Northwest Federal District, 1, 45-55.

Mehraj, H. K., Bhat, A. N., \& Mehraj, H. R. (2014). Impacts of media on society: A sociological perspective. International Journal of Humanities and Social Science Invention, 3(6), 5664.

Official statistics of Russia. http://www.gosstat.ru (accessed date 20.12.2019).

Seregin, S. M. (2015). Formation of a positive image of public authorities through improving the quality of administrative and social services: Research development. Moscow: Altera.

Sokolova, V. M. (2010). Moral Foundations of the civil service of Russia: a textbook. Moscow: RAGS, 115-124.

SoTsis, magazine. http://www.isras.ru/socis.html (accessed date 16.02.2019).

Vetrova E., Medvedeva N., Kabanova E., Evstratova T., \& Senicheva L. (2019) Features and Barriers of Information Interaction between Authorities and Citizens Using E-democracy Technologies at Municipal Level. International Journal of Supply Chain Management, $8(3), 215-221$.

Voitasik, L. (2007). Psychology of political propaganda. Moscow, pp. 89-97. 